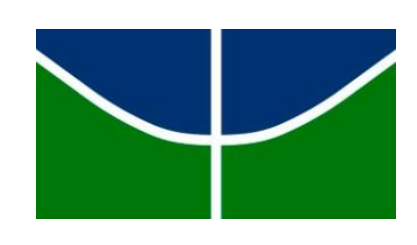

Universidade de Brasília

Faculdade de Agronomia e Medicina Veterinária

PESQUISA DE CLOSTRIDIUM PERFRINGENS EM CARNES BOVINAS EMBALADAS A VÁCUO COMERCIALIZADAS NA REGIÃO DISTRITO FEDERAL E ENTORNO.

IGOR DE OLIVEIRA POTY

DISSERTAÇÃO DE MESTRADO EM SAÚDE ANIMAL

Brasília/DF

Julho/2015 


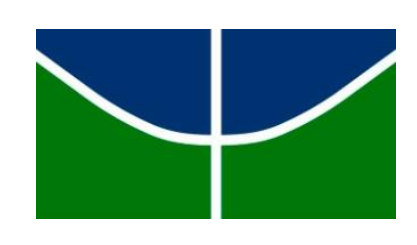

Universidade de Brasília

Faculdade de Agronomia e Medicina Veterinária

\title{
PESQUISA DE CLOSTRIDIUM PERFRINGENS EM CARNES BOVINAS EMBALADAS A VÁCUO COMERCIALIZADAS NA REGIÃO DO DISTRITO FEDERAL E ENTORNO.
}

\author{
IGOR DE OLIVEIRA POTY \\ ORIENTADORA: ÂNGELA PATRICIA SANTANA \\ DISSERTAÇÃO DE MESTRADO EM SAÚDE ANIMAL
}

PUBLICAÇÃO: 112/2015

Brasília/DF

Julho/2015 
UNIVERSIDADE DE BRASÍLIA

FACULDADE DE AGRONOMIA E MEDICINA VETERINÁRIA

PESQUISA DE CLOSTRIDIUM PERFRINGENS EM CARNES BOVINAS

EMBALADAS A VÁCUO COMERCIALIZADAS NA REGIÃO DO DISTRITO

FEDERAL E ENTORNO.

Igor de Oliveira Poty

DISSERTAÇAO DE MESTRADO SUBMETIDA AO PROGRAMA DE PÓS-GRADUAÇÃo EM SAÚdE ANIMAL, COMO PARTE DOS REQUISITOS NECESSÁRIOS À OBTENÇÃo DO TíTULO DE MESTRE EM SAÚDE ANIMAL

APROVADO POR

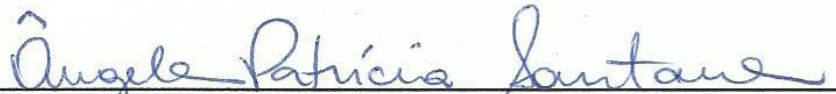

Ângela Patrícia Santana, Prof ${ }^{a}$. Dr ${ }^{a}$. Universidade de Brasília (ORIENTADORA)

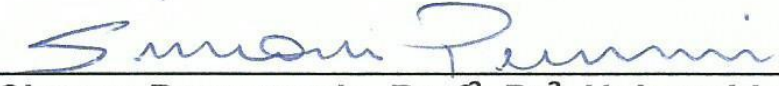

Simone Perecmanis, Prof $^{a}$. Dr ${ }^{a}$. Universidade de Brasília (EXAMINADORA INTERNA)
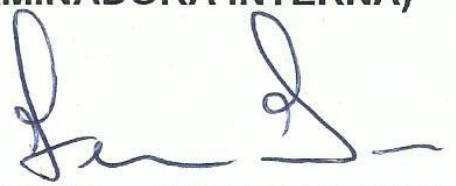

Fernando Araripe Gonçalves Torres, Prof. Dr. Universidade de Brasília (EXAMINADOR EXTERNO)

Brasília, 01 de Julho de 2015 


\section{REFERÊNCIA BIBLIOGRÁFICA E CATALOGAÇÃO}

POTY, I.O. Pesquisa de Clostridium perfringens em carnes bovinas embaladas a vácuo comercializadas na região do Distrito Federal e Entorno. Brasília: Faculdade de Agronomia e Medicina Veterinária, Universidade de Brasília,2015, 42p., Dissertação de Mestrado.

Documento formal autorizando reprodução desta dissertação de mestrado para empréstimo ou comercialização, exclusivamente para fins acadêmicos, foi passado pelo autor à Universidade de Brasília e acha-se arquivado na secretaria do programa. O autor reserva para si os direitos autorais, de publicação. Nenhuma parte desta dissertação de mestrado pode ser reproduzida sem a autorização do autor. Citações são estimuladas, desde que citada a fonte.

\section{FICHA CATALOGRÁFICA}

Poty, Igor de Oliveira

Pesquisa de Clostridium perfringens em carnes bovinas embaladas a vácuo comercializadas na região do Distrito Federal e Entono. / Igor de Oliveira Poty; orientação de Ângela Patricia Santana - Brasília, 2015, 42p, :II

Dissertação de Mestrado (M) - Universidade de Brasília/ Faculdade de Agronomia e Medicina veterinária, 2015.

1.Clostridium perfringens 2. Carne bovina embalada a vácuo 3. Câmara de anaerobiose 4. Toxina cpe. I. POTY, I.O. II. Título. 


\section{AGRADECIMENTOS}

Agradeço ao meu pai, Ubiratan, minha mãe, Simone e minha irmã, Amanda. Nada seria possível sem o apoio de vocês. "O que importa é que estamos juntos."

Obrigado Iraci, por sempre deixar meu quarto limpinho e fazer aquele chá de hortelã! Prometo que em breve volto a te dar carona!

Agradeço a Universidade de Brasília e a Faculdade de Agronomia e Medicina Veterinária, por serem minha segunda casa desde 2006. Aqui fiz os melhores amigos que alguém pode ter.

Agradeço a minha orientadora Ângela Patricia Santana pelo carinho e pela confiança, especialmente nas horas que eu menos tive confiança em mim mesmo. Muito obrigado, profe! (Nunca mais escreverei "de tal maneira").

Agradeço a professora Simone Perecmanis por tirar minhas dúvidas sobre clostrídios no começo do meu projeto.

Ao Professor Fernando Torres, por nos proporcionar a câmara de anaerobiose.

Agradeço a todo pessoal dos laboratórios por sempre serem tão companheiros desde o começo da minha jornada: Narinha, Pâmela, Pati Helena, Pati Renault, Ana Cláudia, Milena, Joana, Thiago, Rebeca Pole Dance, Thaís, Viviane, Flávia, muito obrigado.

Narinha ganha um parágrafo só pra ela! Obrigado por me ensinar praticamente tudo que sei sobre boas práticas no laboratório. Não esqueci que foi você que me ensinou a lavar vidraria, pesar o frango e o que fazer quando o fluxo pega fogo.

Obrigado Ana Lourdes pro me ajudar com a análise estatística. 
Também agradeço ao professor Francisco Lobato e toda a sua equipe do laboratório de anaeróbios da UFMG! Muito Obrigado! Meu trabalho não seria o mesmo sem vocês!

Gustavo e Stela, muito obrigado por me aguentarem nos momentos que surtei! Obrigado por fazerem meus fins de semana tão bons! Obrigado por me ouvirem falar de Doctor Who o tempo todo.

Luana e Ruth, obrigado por não ficarem (muito) zangadas todas as vezes que desmarco alguma coisa com vocês.

Camilla Machuy, não sei se você lembra, mas lá atrás eu estava em duvida se faria ou não o mestrado, obrigado por me encorajar.

Não posso deixar de agradecer a FILHOS, por serem sempre tão gentis comigo e compreensivos com meus horários. Christiane, Rogério, Léo, Larissa, Priscila e Cinthya, trabalhar com vocês me fez crescer muito! Muito obrigado!

Obrigado a todos os amigos que estão no meu coração e não cabem aqui! Obrigado ao CAPES/CNPQ pela bolsa. 


\section{SUMÁRIO}

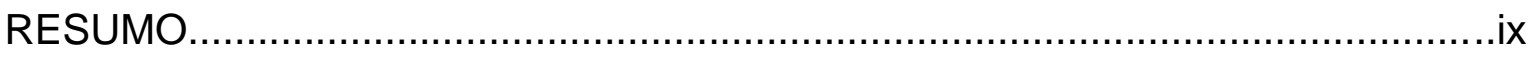

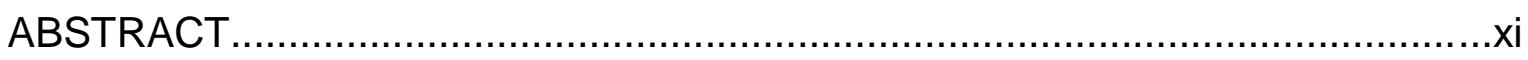

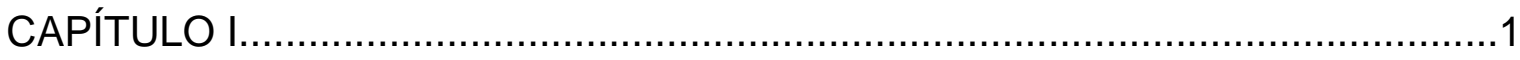

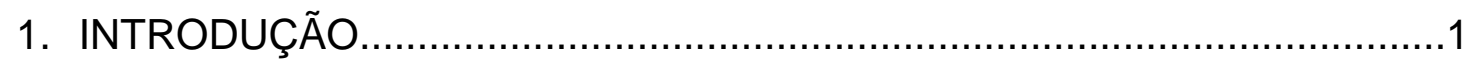

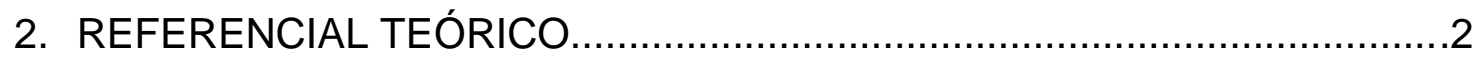

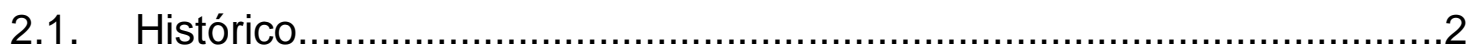

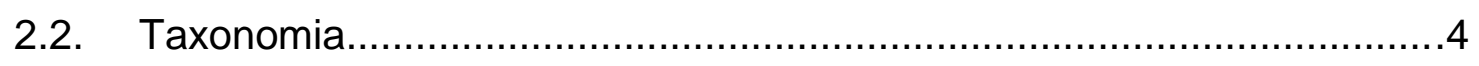

2.3. Caracterização da espécie Clostridium perfringens............................5

2.4. Mecanismo de ação da toxina cpe..............................................

2.5. Distribuição e epidemiologia do Clostridium perfringens em

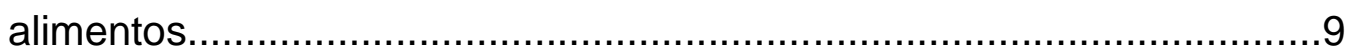

2.6. Funcionamento da câmara de anaerobiose................................10

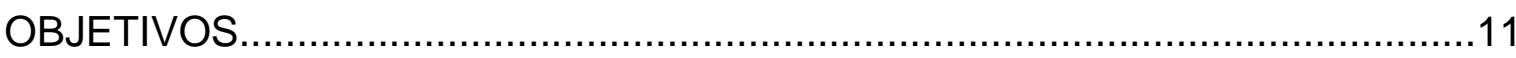

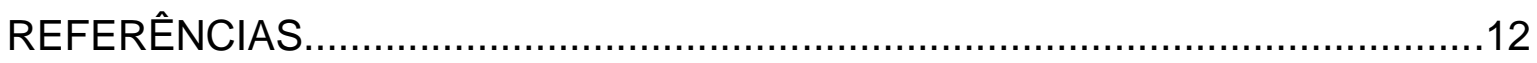

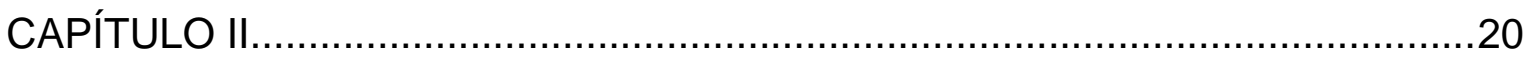

1. INTRODUÇÃ

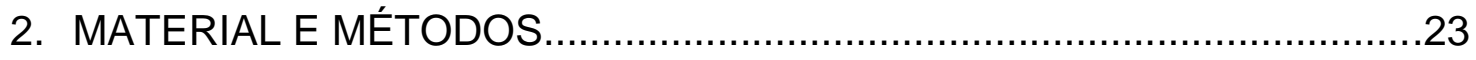

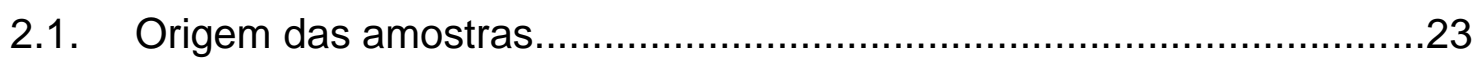

2.2. Isolamento de Clostridium perfringens a partir de $25 \mathrm{~g}$ de amostra de carne bovina. .24

2.3. Isolamento de Clostridium perfringens a partir de exsudato de carne

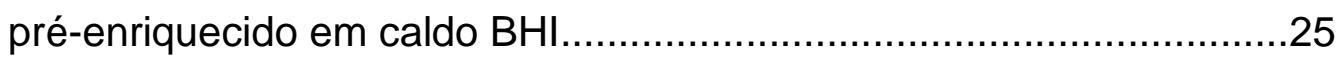

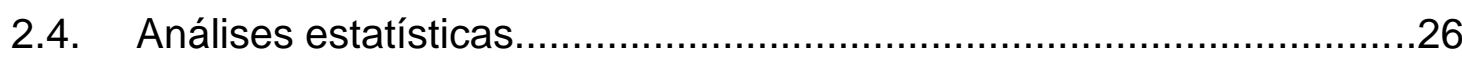


2.5. Detecçao do gene da toxina cpe por reação em cadeia da polimerase. .26

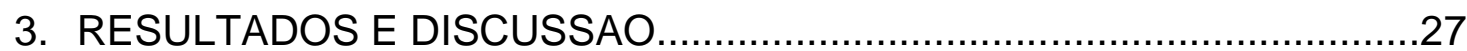

3.1. Isolamento de Clostridium perfringens a partir de 25 gramas de carne bovina. .27

3.2. Isolamento de Clostridium perfringens a partir de exsudato de carne pré-enriquecido com caldo $\mathrm{BHI}$ .28

3.3. Detecção do gene da toxina cpe por reação em cadeia da polimerase(PCR) 32

4. CONCLUSÃO .33

5. REFERÊNCIAS. 34 


\section{RESUMO}

O objetivo deste trabalho foi pesquisar a presença de Clostridium perfringens em 54 amostras de carne bovina embaladas a vácuo comercializadas no Distrito Federal e Entorno, bem como detectar a produção da toxina cpe por PCR, ainda avaliar os meios de cultivo agar SPS $®$ e agar TSC $®$, com e sem etapa de préenriquecimento das amostras em caldo infusão de cérebro e coração $(\mathrm{BHI})$, e incubação tanto em jarra de anaerobiose quanto em câmara de anaerobiose. $\mathrm{Na}$ análise da incubação em Agar SPS $\circledast$ e TSC $\AA$, sem a etapa de préenriquecimento em caldo $\mathrm{BHI}$, observou-se o crescimento em apenas uma $(1,85 \%)$ das 54 amostras analisadas, em ambos os meios de cultivo e formas de incubação. Com a etapa de pré-enriquecimento com caldo BHI em câmara de anaerobiose, observou-se crescimento em todas as 54 amostras (100\%), em ambos os meios de cultivo e formas de incubação. Na reação em cadeia de polimerase (PCR) nenhuma das cepas oriundas das amostras analisadas apresentaram a amplificação de fragmento do gene da toxina cpe. Os resultados evidenciam a presença de $C$. perfringens em carnes embaladas a vácuo comercializadas no Distrito Federal e Entorno, porém não foi detectada a toxina cpeem nenhuma cepa isolada analisada. Na comparação estatística aplicando o teste qui-quadrado de McNemar, observou-se que houve diferença significativa $(p<0,001)$ entre as análises sem e com a etapa de pré-enriquecimento em caldo $\mathrm{BHI}$, verificando-se a influencia positiva do meio na recuperação de esporos, destacando desta forma a importância do enriquecimento prévio em meio $\mathrm{BHI}$ e a 
incubação em câmara de anaerobiose, na recuperação de esporos deste microrganismo.

Palavras-chave: câmara de anaerobiose, toxina cpe, clostridiose alimentar, toxinfecção alimentar, pré-enriquecimento em caldo BHI, Agar SPS, Agar TSC. 


\section{ABSTRACT}

The objective of this study was to evaluate the presence of Clostridium perfringens in vaccum packed beef samples commercialized at Distrito Federal and the Entorno area, as well as to detect the presence of the cpe toxin producing gene by Polymerase chain reaction (PCR), also evaluate the culture medium SPS® agar and TSC $\AA$ agar, with and without pre-enrichment step of the samples in Brain Heart Infusion (BHI) broth, and to promote the incubation in anaerobic jar and anaerobic chamber. The results of the incubation on SPS® agar and TSC $\AA$ agar, without the pre-enrichment step in $\mathrm{BHI}$, growth was observed at only $1(1,85 \%)$ of the 54 analyzed samples, in both culture media and incubation methods. With the pre-enrichment step in $\mathrm{BHI}$ broth at the anaerobic chamber, growth was observed in all of the 54 samples (100\%), in both culture media and incubation methods. At the PCR, none of the strains detected from the analyzed samplespresented amplification of the fragment of the cpe toxin gene. The results showed the presence of $C$. perfringens in vaccum packed beef samples commercialized at the Distrito Federal and Entorno area, however the cpe toxin wasn't detected in none of the analyzed samples. In statistical analysis, using McNemar's qui-square test, a significant difference $(p<0,001)$ was observed between the analysis with and without pre-enrichment step in $\mathrm{BHI}$ broth, verifying the positive influence of the medium in spore recovery, therefore to enhance the importance of the preenrichment stage in $\mathrm{BHI}$ broth and the incubation in anaerobic chamber in spore recovery for this microorganism.

Keywords: anaerobic chamber, cpe toxin, foodborne clostridiosis, foodborne intoxication, pre-enrichment in BHI broth, agar SPS, agar TSC 


\section{CAPÍTULO I}

\section{INTRODUÇÃO}

O Clostidium perfringens é uma bactéria presente na microbiota normal de animais e humanos (SILVA et al., 2015; MIYAMOTO et al., 2015; VERHERSTRAETEN et al., 2015). É capaz de causar doenças tanto pela produção de toxinas, quanto pela invasão de tecidos, tendo como principais portas de entrada no organismo a ingestão de alimentos contaminados, lesões de pele e inalação (LOBATO et al., 2010). Este microrganismo é capaz de desenvolver-se em grande amplitude térmica, sendo possível observar crescimento entre $10^{\circ} \mathrm{C}$ e $47^{\circ} \mathrm{C}$. Ao serem expostos a temperaturas normais de cozimento, seus esporos não são inativados, podendo, ao contrário, serem ativados e se multiplicarem durante o resfriamento do alimento (HUANG, 2015).

O microrganismo é capaz de produzir 16 tipos de toxinas, dentre as quais se destacam: alfa, beta, épsilon e iota. A classificação das cepas de $C$. perfringens se dá de acordo com as toxinas produzidas (LINDEN et al., 2015; ALVES et al., 2014; NIILO, 1980). Também se destaca a toxina cpe, responsável pelos surtos de toxinfecção alimentar (BLACK et al., 2015; PIRES, 2011; SILVA et al; 2010).

A clostridiose alimentar em humanos causa uma dor abdominal de média intensidade por um curto período de tempo e, em mais de $90 \%$ dos casos, acompanhada de diarreia (SIMONE et al., 2014). O período de incubação é de 6 a 24 horas, mais frequentemente de 10 a 12 horas, durando em torno de 24 horas em maior parte da população, e nos idosos pode durar até duas semanas (SILVA, 2010). 
No Brasil, entre os anos 2000 e 2014, o C. perfringens foi diagnosticado em $5,3 \%$ dos surtos de doenças transmitidas por alimentos, porém em $51,4 \%$ do total de surtos o agente etiológico não foi identificado (BRASIL, 2014). Nos Estados Unidos estima-se que o $C$. perfringens seja a segunda maior causa de doenças transmitidas por alimentos, provocando um milhão de infecções por ano (GRASS et al., 2013).

No cultivo deste microrganismo, a técnica de passivação do cobre é um método clássico e utilizado por vários pesquisadores, por ser uma maneira eficaz de se gerar anaerobiose ou microaerofilia. Contudo, a utilização da câmara de anaerobiose tem se tornado mais frequente, pela sua capacidade de não apenas gerar uma atmosfera anaeróbia, mas também permitir a manipulação de espécies em ambiente completamente anaeróbio (JOUSIMIES-SOMER et al., 2002).

Em decorrência da relevância que essa bactéria apresenta para saúde pública, as particularidades de seu cultivo, e a relevância da toxina cpe em surtos de toxoinfecções alimentares, e levando em consideração a escassez de dados sobre o microrganismo na região do Distrito Federal e Entorno, este trabalho se propõe a pesquisar a presença deste microrganismo em carnes embaladas a vácuo, bem como avaliar a eficiência de seus métodos de cultivo.

\section{REFERENCIAL TEÓRICO}

\subsection{Histórico}

O primeiro relato sobre o microrganismo ocorreu em 1890, por William $\mathrm{H}$. Welch, após uma necropsia humana realizada por ele e seus colegas. Nesta necropsia foi observado que o paciente apresentava um tumor crescente próximo 
a clavícula. Também foi encontrado um enfisema difuso e crepitante ao toque, espalhado próximo a tireóide, axilas, face interna dos braços, face interna das coxas, virilha e nádegas. Na tentativa de descobrir a natureza do gás, acendeu-se uma chama próximo ao cadáver, provocando uma pequena explosão com chama azul clara, fazendo-os acreditar na presença de hidrogênio no gás produzido (LUCEY\& GROVER, 2004).

Ao exame microscópico do sangue e órgãos do paciente, observou-se uma grande quantidade de bacilos, descritos por Welch como "possuem 3 a $5 \mathrm{~mm}$ de comprimento, da espessura de um bacilo de Anthraz, com pontas levemente arredondadas, às vezes quase quadradas, ocorrendo normalmente em pares ou grupos”. Nenhuma outra bactéria foi observada em qualquer lâmina preparada a partir dos tecidos do paciente. Essa nova bactéria passou a ser chamada de Bacillus aerogenes capsulatus, e mais tarde de Bacillus welchii, em homenagem a William H. Welch. (LUCEY \& GROVER, 2004)

Até então se acreditava que a produção de gás em cadáveres era um processo que ocorria naturalmente durante a putrefação, já que o ar seria um importante componente da circulação sanguínea. Após seus trabalhos, ficou claro que o inflar dos tecidos após a morte é, de fato, decorrente da ação de bactérias. Também se destacou a importância desse microrganismo em feridas profundas, especialmente quando associado a bactérias piogênicas (KLOTZ \& HOLMAN, 1911).

Após seu descobrimento, pesquisadores na França e Alemanha começaram a reportar achados semelhantes ao de Welch, porém, como foi encontrado em locais distintos, o Bacillus welchii recebeu nomenclaturas diferentes (KLOTZ \& HOLMAN, 1911). Frankel encontrou um grande bacilo 
anaeróbio no fleuma de lesões com produção de gás e o chamou de Bacillus phlegmones emphysematosae. Veilon e Zuber isolaram bacilos provenientes de casos de otites medias, gangrena pulmonar, apendicite e o nomearam Bacillus perfringens. Lindenthal também obteve sucesso em isolar o microrganismo a partir de enfisemas vaginais, o qual chamou de Bacillus emphysematis vaginae. $O$ primeiro isolamento em alimentos foi feito por Schattenfroh e Grassberger, que encontraram o bacilo em água e leite, passando a chamá-lo de Granulobacillus saccharobutyricus immobilis liquefaciens. (KLOTZ \& HOLMAN, 1911; WELCH, 1910)

\subsection{Taxonomia}

De acordo com o National Center for Biotechnology Information(2015), a classificação do Clostridium perfringens apresenta-se atualmente da seguinte forma:

Reino Bacteria

Filo Firmicutes

Classe Clostridia

Ordem Clostridiales

Família Clostridiaceae

Género Clostridium

Espécie Clostridium perfringens 


\subsection{Caracterização da espécie Clostridium perfringens}

Clostridium perfringens é um bacilo anaeróbio, formador de esporos, grampositivo, comumente encontrado no solo e no trato gastrointestinal, biliar e urinário de humanos e animais como parte da microbiota normal (SILVA et al., 2015; YAMAGUCHI et al., 2015; REDONDO et al., 2015).

Dentre os agentes bacterianos mais comuns e economicamente importantes, o C. perfringens se destaca por estar entre os mais amplamente disseminados, sendo considerado ubíquo (COSTA et al., 2004). É uma espécie muito importante por estar envolvida em clostridioses entéricas, tanto em humanos quanto em animais, acarretando problemas não apenas para a produção animal, mas também para a saúde pública como um todo (SILVA et al., 2015; MIYAMOTO et al., 2012). É capaz de produzir diversas toxinas, dentre as quais quatro se destacam: alfa, beta, épsilon e iota. Considerando a produção destas toxinas, são classificados de A a E (NIILO, 1980). Outras toxinas, como a enterotoxina (cpe), são consideradas importantes fatores de virulência deste microrganismo (VIEIRA et al., 2008). De tal maneira que caracteriza um grupo heterogêneo de microrganismos, com vias metabólicas, toxinas e patogenicidade distintas. Quadro 1. (NIILO, 1980) 
Quadro 1. Principais toxinas produzidas pelos cinco tipos de Clostridium perfringens.

\begin{tabular}{|cccccc|}
\hline Tipo & Alfa & beta & Épsilon & iota & Enterotoxina \\
\hline A & + & - & - & - & $+/-$ \\
B & + & + & + & - & $+/-$ \\
C & + & + & - & - & $+/-$ \\
D & + & - & + & - & $+/-$ \\
E & + & - & - & + & $+/-$ \\
\hline
\end{tabular}

Fonte adaptada: PIRES (2011)

C. perfringens tipo A é o mais comum dentre os tipos de Clostridium, também é o que produz a maior variedade de toxinas, podendo ser dividido em duas variedades: a "clássica" e a enterotoxigenica. A forma clássica é caracterizada por provocar gangrena gasosa, infecções pós-traumáticas, enterite necrótica aviária e mastite necrótica (NIILO, 1980). A forma enterotoxigenica leva a surtos de toxinfecção alimentar em humanos, enteropatias em caprinos e quadros diarréicos em suínos (NIILO et al., 1980; FERNANDEZ-MIYAKAWA et al., 2007).

Em cães e gatos, o papel do Clostridium perfringens ainda não foi completamente esclarecido, podendo estar associado tanto a uma diarréia branda e auto-limitante, quanto a uma enterite necrótica hemorrágica fatal. (SILVA \& LOBATO, 2015) 


\subsection{Mecanismo de ação da toxina cpe}

A enterotoxina cpe produzida pelo $C$. perfringens é uma proteína simples pesando aproximadamente 35.000 Da. Esta enterotoxina induz efusão de líquidos para interior do trato intestinal por alteração na permeabilidade de membrana (KATAHIRA et al, 1997a). Além do trato intestinal, a toxina também foi encontrada ligada a receptores nos rins e fígado em ratos inoculados experimentalmente (KATAHIRA et al, 1997b). A enterotoxina possui um domínio N-terminal (N-cpe), responsável pelo seu caráter citotóxico, e uma extremidade C- terminal (C-cpe), responsável por sua aderência à parede da célula (EBIHARA et al., 2006).

Ao entrar em um hospedeiro humano, ou animal, é comum que microrganismos bacterianos passem por alterações na expressão de seus genes, essas alterações incluem a síntese de fatores de virulência tais como novas toxinas. C. perfringens se comporta de maneira pouco usual, nesta situação. Depois da ingestão de alimento contaminado, o microrganismo se depara com um ambiente pouco favorável ao seu desenvolvimento no estômago e no intestino delgado, dando inicio ao processo de esporulação (CZECZULIN et al, 1993), sendo durante a fase de esporulação que $C$. perfringens produz a enterotoxina (CZECZULIN et al, 1993; SILVA et al; 2010).

O mecanismo de ação da toxina cpe envolve as seguintes etapas: ligação da toxina cpe a receptores de membranas, inserção na enterotoxina na membrana plasmática, formação de complexo entre enterotoxina e membrana plasmática, aumento da permeabilidade de membrana para íons, indução de efeitos secundários que levarão a célula à morte (CZECZULIN et al, 1993). 
Dentre as proteínas de membrana envolvidas no mecanismo de ação da toxina cpe, destacam-se as claudinas, uma família de 27 proteínas, de aproximadamente 23,000 Da, que atuam como componentes das junções celulares (CHAOUCHE-MAZOUNI et al., 2015; EBIHARA et al., 2006). As claudinas $1,4,5,7,8,11,14$, e 19 são claudinas de impermeabilidade, sua expressão aumenta a junção intercelular e diminui a permeabilidade células. As claudinas 2, 10 e 16 são formadoras de poros, um aumento na sua expressão provoca diminuição na junção entre as células (ALIKANOGLU et al., 2015).

As claudinas 3 e 4 estão presentes em grandes quantidades em diversos tipos de câncer, incluindo câncer de ovário, útero, mama, próstata e pâncreas. Estas proteínas também estão sendo pesquisadas em carcinoma seroso de útero, carcinosarcoma e câncer seroso de ovário, que são conhecidos por sua agressividade. A claudina 3 é expressa em maiores quantidades em tumores com maior grau de malignidade, como câncer colorretal e câncer de mama (BLACK et al., 2015).

A toxina cpe se liga às claudinas 3 e 4 , chamadas de receptores cpe, e também a outros componentes da família das claudinas (cld). Após a ligação da toxina cpe via seu domínio C-terminal, a formação de poros na célula é induzida pelo domínio $\mathrm{N}$-terminal, que causa a morte da célula. O domínio C-terminal em si não é citotóxico, ele aumenta a permeabilidade paracelular e pode ser usado para aprimorar a passagem de medicamentos através das barreiras celulares (VESHNYAKOVA et al., 2012). 


\subsection{Distribuição e epidemiologia do Clostridium perfringens em alimentos.}

C. perfringens é um microrganismo presente na microbiota normal do trato intestinal de humanos e animais. Seus esporos podem resistir no solo, fezes e no ambiente (SILVA et al., 2015; SWIFT et al., 2015). Surtos normalmente são reportados após o consumo de refeições preparadas para um grande número de pessoas, normalmente envolvendo pratos a base de carne ou frango mantido sob temperatura inadequada após seu cozimento (ACHESON et al., 2015)

GOULD et al. (2013) relatam que, entre 1998 e 2008, a carne bovina foi o principal veículo de toxinfecções causadas pelo C. perfringens, sendo responsável por $41,8 \%$ do total de toxinfecções causadas pelo microrganismo, seguida pela carne de frango, com $30 \%$ e por último a carne suína, com $16,3 \%$. Ainda é relatado pelos autores que, com o passar dos anos, foi observado um declínio na contaminação pela carne bovina e um aumento na contaminação por carne de frango, porém estatisticamente irrelevantes. De acordo com SCALLAN et al. (2011) C. perfringens é responsável por $11 \%$ do total de toxinfecções alimentares nos Estados Unidos.

VAILLANT et al. (2005) observaram que na França entre os anos 1997 e 2000, todas as hospitalizações ocasionadas por C. perfringens tiveram origem alimentar. Também relatam que pode haver mais casos de $C$. perfringens que não foram reportados, devido a falta de informações acerca do microrganismo.

Entre os anos de 1992 e 2008, o C. perfringens foi identificado como agente etiológico de toxinfecções alimentares em 10\% dos casos de casos reportados na Inglaterra e no País de Gales (SIMONE et al., 2014). 
No Brasil, entre os anos 2000 e 2014, 51,4\% dos casos de toxinfecção alimentar, o agente etiológico não foi identificado. Similarmente, e em 4308 casos de toxinfecção alimentar, o alimento não foi identificado. O C. perfringens foi o sexto microrganismo mais associado a casos de toxinfecção alimentares, correspondendo a $5,3 \%$ dos casos (BRASIL, 2014).

\subsection{Funcionamento da câmara de anaerobiose}

A câmara de anaerobiose consiste em um gabinete principal com atmosfera composta por uma mistura de gases contendo $85 \% \mathrm{~N}_{2}, 10 \% \mathrm{CO}_{2}, 5 \% \mathrm{H}_{2}$, e uma antecâmara onde são acondicionadas as amostras antes de passarem para o gabinete principal. $\mathrm{Na}$ antecâmara é feita a retirada de todo oxigênio da amostra, o processo ocorre da seguinte maneira: Um ciclo de vácuo (onde o ar da antecâmara é puxado por um compressor de ar), um ciclo de gás nitrogênio com 99,99\% de pureza, um segundo ciclo de vácuo, um novo ciclo de nitrogênio, um último ciclo de vácuo e um ciclo com a já referida mistura de gases (JOUSIMIESSOMER et al., 2002; THERMO SCIENTIFIC, 1994).

O resíduo de oxigênio é eliminado pelos catalisadores que existem dentro da câmara: carvão ativado, paládio e dessecante. O catalisador de carvão ativado elimina resíduos de $\mathrm{H}_{2} \mathrm{~S}$, comumente produzidos por anaeróbios. O paládio usa o $\mathrm{H}_{2}$ presente na atmosfera anaeróbia para eliminar oxigênio residual na forma de água $\left(\mathrm{H}_{2} \mathrm{O}\right)$, que é absorvida pelo dessecante (THERMO SCIENTIFIC, 1994). 


\section{OBJETIVOS}

\section{Objetivo Principal}

Realizar a pesquisa de Clostridium perfringens em carnes bovinas embaladas a vácuo, comercializadas na região do Distrito Federal e Entorno.

\section{Objetivos específicos}

- Comparar o cultivo em ágar SPS e ágar TSC;

- Comparar o cultivo de C. perfringens em jarra de anaerobiose, utilizando a passivação do cobre como método de geração de anaerobiose, e o cultivo em câmara de anaerobiose com mistura de gases contendo $85 \% \mathrm{~N}_{2}, 10 \%$ $\mathrm{CO}_{2}$ e $5 \% \mathrm{H}_{2}$

- Avaliar a influencia da incubação das amostras em caldo BHI, em etapa de enriquecimento prévio;

- Detectar a presença da toxina cpe nas cepas isoladas por reação em cadeia da polimerase (PCR). 


\section{REFERÊNCIAS}

ACHESON, P.; BELL V.; GIBSON, J.; GORTON, R.; INNS, T.Enforcement of science-using a Clostridium perfringens outbreak investigation to take legal action.Journal of Public Health. V. 13. 2015

ALIKANOGLU, A.S.; GUNDUZ, S.; DEMIRPENCE, O.; SUREN, D.; GUNDUZ, U.R.; SEZER, C.; YILDIZ, M.; YILDIRIM, M. Expression pattern and prognostic significance of claudin 1, 4 and 7 in pancreatic cancer.Asian Pacific Journal of Cancer Prevention.V.16, n. 10, pag. 4387-4392. 2015

ALVES, G.G.; MACHADO DE ÁVILA, R.A.; CHÁVEZ-OLÓRTEGUI, C.D.; LOBATO, F.C. Clostridium perfringens epsilon toxin: the third most potent bacterial toxin known. Anaerobe.N.30, pag.102-107. 2014.

BLACK, J.D.; LOPEZ, S.; COCCO, E.; SCHWAB, C.L.; ENGLISH, D.P.; SANTIN, A.D. Clostridium perfringens enterotoxin (CPE) and CPE-binding domain (c-CPE) for the detection and treatment of gynecologic cancers.Toxins. V. 7, n. 4, pag. 1116-1125. 2015.

BRASIL; MINISTÉRIO DA SAÚDE; DEPARTAMENTO DE VIGILANCIA EPIDEMIOLÓGICA; COORDENAÇÃO GERAL DE DOENÇAS TRANSMISSÍVEIS. Vigilancia Epidemiológica das Doenças Transmitidas por Alimentos - VE-DTA. São Paulo. 2014. Disponível em <http://www.anrbrasil.org.br/new/pdfs/2014/3_PAINEL_1_ApresentacaoRejaneAlv 
esVigilanciaEpidemiologica-VE-DTA-Agosto_2014_PDF.pdf>. Ultimo acesso em: 18 de Junho de 2015

CHAOUCHE-MAZOUNI, S.; SCHERPEREEL, A.; ZAAMOUM, R.; MIHALACHE, A.; AMIR, ZC.; LEBAÏLI, N.; DELAIRE, B.; GOSSET, P. Claudin 3, 4, and 15 expression in solid tumors of lung adenocarcinomaversus malignant pleura I mesothelioma. Annals of Diagnostic Pathology. N. 15, pag, 49-50. 2015.

COSTA, G.M.; ASSIS, R.A.; LOBATO, F.C.F.; ABREU, V. L. V.; SANTOS, J. L.; UZAL, F. A. Diarréia em leitões lactentes por Clostridium perfringens tipo A em granjas tecnificadas nos estados de Minas Gerais e São Paulo. Arquivo Brasileiro de Medicina Veterinária e Zootecnia. Vol. 56, n. 3. 2004.

CZECZULIN, J.R.; HANNA, P.C.; MCCLANE, B.A.Cloning, nucleotide sequencing, and expression of the Clostridium perfringens enterotoxin gene in Escherichia coli.Infection and Immunity.V.61, n.8, pag.3429-3439. 1993.

EBIHARA, C.; KONDOH, M.; HASUIKE, N.; HARADA, M.; MIZUGUCHI, H.; HORIGUCHI, Y.; FUJII, M.; WATANABE, Y. Preparation of a claudin-targeting molecule using a C-terminal fragment of Clostridium perfringens enterotoxin. The Journal of Pharmacology and Experimental Therapeutics. V. 316, n.1, pag 255-260. 2006. 
FERNANDEZ-MIYAKAWA, M.E, MARCELLINO, R, UZAL, F.A. Clostridium perfringens type A toxin production in 3 commonly used culture media. Journal of Veterinary Diagnostic Investigation. V.19, n.2, pag.184-186. 2007.

GRASS, J.E.; GOULD, L.H.; MAHON, B.E. Epidemiology of foodborne disease outbreaks caused by Clostridium perfringens, United States, 1998-2010. Foodborne Pathogens and Diseases.V.10, n.2, pag.131-136. 2013.

GOULD, L.H.; WALSH, K.A.; VIEIRA, A.R.; HERMAN, K.; WILLIAMS, I.T.; HALL, A.J.; COLE, D.; Centers for Disease Control and Prevention.Surveillance for foodborne disease outbreaks - United States, 1998-2008. Morbidity and Mortality Weekly Report. V. 62, n.2, pag. 1-34. 2013.

HUANG, L. Dynamic determination of kinetic parameters, computer simulation, and probabilistic analysis of growth of Clostridium perfringens in cooked beef during cooling. International Journal of Food Microbiology.n.195pag. 20-29. 2015

JOUSIMIES-SOMER, H. WADSWORTH-KTL Anaerobic Bacteriology Manual. 6a edição. Editora Starpub. 287 páginas. 2002.

KATAHIRA, J.; INOUE, N.; HORIGUCHI, Y,; MATSUDA, M.; SUGIMOTO, N. Molecular cloning and functional characterization of the receptor for Clostridium perfringens enterotoxin.The Journal of Cell Biology. V.136, n. 6, pag. 1239-1247. 1997a 
KATAHIRA, J.; SUGIYAMA, H.; INOUE, N.; HORIGUCHI, Y.; MATSUDA, M.; SUGIMOTO, N. Clostridium perfringens enterotoxin utilizes two structurally related membrane proteins as functional receptors in vivo.The Journal of Biological Chemistry. V.272, n. 42, pag. 26652-26658. 1997b

KLOTZ, O.; HOLMANN, W.L. Infection by the Gas Bacillus in Coal-Mines. The Journal of Infectious Diseases.Vol. 9, No. 3 pag.251-264. 1911.Disponívelem<http://www.jstor.org/stable/30073333>.Ultimo acesso em 23 de Junho de 2015.

LINDEN, J.R.; MA, Y.; ZHAO, B.; HARRIS, JM.; RUMAH, K.R.; SCHAERENWIEMERS, N. VARTANIAN, T. Clostridium perfringens Epsilon Toxin Causes Selective Death of Mature Oligodendrocytes and Central Nervous System Demyelination. MBio. V. 6, n. 3. 2015

LOBATO, F.C.; LIMA, C.G.; ASSIS, R.A.; PIRES, P.S; SILVA, R.O.; SALVARANI, F.M.; CARMO, A.O.; CONTIGLI, C.; KALAPOTHAKIS, E. Potency against enterotoxemia of a recombinant Clostridium perfringens type $D$ epsilon toxoid in ruminants.Vaccine.V.28 n.38 pag.6125-7. 2010.

LUCEY, B.P.; GROVER, M.H. William H. Welch, MD, and the discovery of Bacillus welchii. Archives of Pathology and Laboratory Medicine.V.128, n.10, pag.1193-1195. 2004. 
MANGEN, M.J; BOUWKNEGT, M.; FRIESEMA, I.H.; HAAGSMA, J.A.; KORTBEEK, L.M.; TARIQ, L.; WILSON, M.; VAN PELT, W.; HAVELAAR, AH.Cost-of-illness and disease burden of food-related pathogens in the Netherlands, 2011. International Journal of Food Microbiology.V. 196, pag. 8493. 2014.

MIYAMOTO, K.; LI, J.; MCCLANE, BA.Enterotoxigenic Clostridium perfringens: detection and identification. Microbes and Enviroments.V.27, n.4, pag.343-349, 2012.

MIYAMOTO, K.; SEIKE, S.; TAKAGISHI, T.; OKUI, K.; ODA, M.; TAKEHARA, M.; NAGAHAMA, M. Identification of the replication region in pBCNF5603, a bacteriocin-encoding plasmid, in the enterotoxigenic Clostridium perfringens strain F5603. BMC Microbiology. V. 15, pag. 118. 2015

NATIONAL CENTER FOR BIOTECHNOLOGY INFORMATION.Clostridium perfringens.Taxonomy. 2015. Disponível em:

<http://www.ncbi.nlm.nih.gov/Taxonomy/Browser/wwwtax.cgi?id=1502>. Ultimo acesso: 22 de Junho de 2015.

NIILO, L. Clostridium perfringens in animal disease: a reviewofcurrentknowledge. Canadian Veterinary Journal. V.21, n.5, pag. 141-148. 1980.

PIRES, P.S.P.; SILVA, R.O.S.; LOBATO, F.C.F. Clostridiose alimentar Clostridium perfringens. Programa de zoonoses - região sul. 2011 Disponível em: 
<http://www.zoonoses.org.br/absoluto/midia/imagens/zoonoses/arquivos_1330097 103/3829_clostridiose_alimentar_c_perfringens.pdf>. Ultimo acesso em: 08 de junho de 2015.

REDONDO, L.M.; DOMINGUEZ, J.E.; RABINOVITZ, B.C.; REDONDO, E.A.; MIYAKAWA, M.E. Hydrolysable and condensed tannins resistance in Clostridium perfringens. Anaerobe. 2015.

SCALLAN, E.; HOEKSTRA, R.M.; ANGULO, F.J.; TAUXE, R.V.; WIDDOWSON, M.A.; ROY, S.L.; JONES, J.L.; GRIFFIN, P.M. Foodborne illness acquired in the United States--major pathogens.Emerging Infectious Diseases. V. 17, n.1 ,pag 7-15. 2011

SILVA, R.O.; LOBATO, F.C. Clostridium perfringens: A review of enteric diseases in dogs, cats and wild animals. Anaerobe. N. 33, pag. 14-17. 2015.

SILVA, N. Manual de métodos de análise microbiológica de alimentos e água. 4.ed. São Paulo: Varela, 2010.

SILVA, R.O.S.; OLIVEIRA JUNIOR, C.A; GUEDES, R.M.C; LOBATO, F.C.F. Clostridium perfringens: a reviewofthedisease in pigs, horsesandbroilerchickens. Ciencia Rural [online]. V. 45 N.6 pag.1027-1034. 2015. 
SIMONE, B.; ATCHISON, C.; RUIZ, B.; GREENOP, P.; DAVE, J.; READY, D.; MAGUIRE, H.; WALSH, B.; ANDERSON, S. Investigating an outbreak of Clostridium perfringens gastroenteritis in a school using smartphone technology, London, March 2013. Euro Surveillance. V.15, n.19,. 2014.

SWIFT, S.M.; SEAL, B.S.; GARRISH, JK.; OAKLEY, BB.; HIETT, K.; YEH, HY.; WOOLSEY, R.; SCHEGG, KM.; LINE, JE.; DONOVAN, D.M. A Thermophilic Phage Endolysin Fusion to a Clostridium perfringens-Specific Cell Wall Binding Domain Creates an Anti-Clostridium Antimicrobial with Improved Thermostability. Viruses.V.7, n.6, pag 3019-34.

THERMO SCIENTIFIC.Operating and Maintenance Manual 7011025 Rev. 13.Thermo Scientific. 1994.

VAILLANT, V.; DE VALK, H.; BARON, E.; ANCELLE, T.; COLIN, P.; DELMAS, MC.; DUFOUR, B.; POUILLOT, R.; LE STRAT, Y.; WEINBRECK, P.; JOUGLA, E.; DESENCLOS, J.C. Foodborne infections in France.Foodborne pathogens and diseases.V.2, n.3, pag.221-232. 2005.

VeRHERStRAeten, S.; GOOSSENS, E.; VALGAEREN, B.; PARDON, B.; TIMBERMONT, L.; HAESEBROUCK, F.; DUCATELLE, R.; DEPREZ, P.; WADE, K. R.; TEWTEN, R.; VAN IMMERSEEL, F. Perfringolysin O: The Underrated Clostridium perfringens Toxin?. Toxins (Basel). V. 7, n. 5, pag. 17021721. 2015 
VESHNYAKOVA, A.; PIONTEK, J.; PROTZE, J.; WAZIRI, N.; HEISE, I.; KRAUSE, G. Mechanism of Clostridium perfringens enterotoxin interaction with claudin-3/-4 protein suggests structural modifications of the toxin to target specific claudins. Journal of Biologic Chemistry. V. 287, n.3, pag. 1698-1708. 2012.

VIEIRA, A.S.S.; GUEDES, R.C.M.; SALVARINI, F.M.; SILVA, R.O.S.; ASSIS, R.A.; LOBATO, F.C.F. Genotipagem de Clostridium perfringens isolados de leitões diarréicos. Arquivos do Instituto Biológico. V.75, n.4, pag.513-516. 2008.

WELCH, W.H. Distribution of Bacillus aerogenes capsulatus (Bacillus welchii, migula). Journal of the Boston Society of Medical Sciences.V.5, n.7, pag.369370. 1910.

Disponível

em

<http://www.ncbi.nlm.nih.gov/pmc/articles/PMC2048464/>. Ultimo acesso em: 23 de Junho de 2015.

YAMAGUCHI, R.; MAKINO, Y.; CHIBA, F.; MOTOMURA, A.; INOKUCHI G.; YAJIMA D.; IWASE H. Fatal Clostridium perfringens septicemia suggested by postmortem computed tomography: A medico-legal autopsy case report. Forensic Sciense International. 2015. 


\section{CAPÍTULO II}

\section{PESQUISA DE CLOSTRIDIUM PERFRINGENS EM CARNES BOVINAS EMBALADAS A VÁCUO COMERCIALIZADAS NA REGIÃO DO DISTRITO FEDERAL E ENTORNO.}

\section{INTRODUÇÃO}

O Clostridium perfringens é um bacilo anaeróbio, esporulante e faz parte da microbiota normal do trato gastrointestinal e urinário de humanos e animais, sendo também encontrado nas águas de rios e no solo (SHINDO et al., 2015; DESMARAIS, 2002). Tanto em humanos quanto em animais, C. perfringens provoca infecções e doenças histotóxicas originarias no intestino, como enterites e enterotoxemias (CHEN et al., 2014; LI \& MACCLANE, 2013). Este microrganismo provoca doenças tanto pela produção de toxinas, quanto pela invasão de tecidos, tendo como porta de entrada a ingestão de alimentos contaminados, lesões de pele e inalação. As toxinas podem ser produzidas no próprio organismo após a infecção ou então são ingeridas pré-formadas (LOBATO et al., 2010).

O C. perfringens é classificado em 5 tipos toxigênicos de $A$ a $E$, dependendo da toxina produzida. Além das 4 principais toxinas produzidas (alfa, beta, épsilon e iota), existem outras 17 toxinas que podem ou não estar associadas a quadros clínicos em humanos e em animais. Dentre as toxinas, a 
enterotoxina (cpe) tem papel confirmado nos casos de toxinfecção alimentar causada pelo mesmo (PIRES et al., 2011).

O cultivo de $C$. perfringens em jarra de anaerobiose, com a passivação do cobre como meio gerador de anaerobiose é um método clássico e utilizado até hoje no Brasil e em diversas partes do mundo. Porém dentre os métodos de cultivos de anaeróbios, o uso da câmara de anaerobiose se mostra a mais eficiente, pois propicia a capacidade de visualizar as colônias sem retirá-las da anaerobiose. A câmara é formada por um gabinete de plástico com luvas seladas a ele. Dentro do gabinete há uma mistura especial de gases contendo $85 \%$ N2, $10 \% \mathrm{CO}_{2}, 5 \% \mathrm{H}_{2}$, porém também podem ser encontradas misturas contendo $95 \%$ $\mathrm{N}_{2}$ e $5 \% \mathrm{H}_{2}$ (JOUSIMIES-SOMER et al., 2002). Dessa maneira, é possível garantir que a atmosfera dentro da câmara seja completamente anaeróbia.

Para o diagnóstico de $C$. perfringens em carnes e derivados, é possível utilizar o caldo e o ágar BHI (Brain Heart Infusion), cuja função é induzir a germinação de esporos, sendo utilizado por diversos pesquisadores (KANEKO et al., 2011; AKHTAR et al., 2009; WEN \& MACLANE, 2004). O caldo BHI tem sido utilizado no diagnóstico de clostridioses em animais, devido a sua eficiência na germinação de esporos (PAREDES-SABJA\& CARTER; 2012; GOLDSTEIN et al., 2012; FERNANDEZ-MIYAKAWA et al., 2007). Os meios de cultivo mais usados para o isolamento de $C$. perfringens são o ágar Sulfito Polimixina Sulfadiazina (SPS) e o ágar Triptose Sulfito Cicloserina (TSC) (SILVA et al., 2010).

De acordo com a Agência Nacional de Vigilância Sanitária, a toxinfecção alimentar por $C$. perfringens é a sexta mais frequente no Brasil, entretanto devese notar que em $51,34 \%$ de todos os casos de toxinfecção alimentar o agente causador é ignorado (BRASIL, 2014). Nos Estados Unidos e no Canadá, a 
toxinfecção alimentar por $C$. perfringens é uma das mais comumente diagnosticadas (CDC, 2014; PHAC, 2012). O microrganismo já foi isolado a partir produtos derivados de carne bovina em diversos países como Jordânia, Costa do Marfim, Turquia, Estados Unidos e Holanda (AL-QADIRI et al., 2015;HUANG, 2015;KOUASSI et al., 2014; XIAO, 2014). Além do isolamento microbiológico, o diagnóstico molecular de $C$. perfringens a partir da toxina cpe vem sendo largamente usada por diversos pesquisadores tendo em vista a existência de diferenças na virulência entre as cepas (KANEKO et al., 2011; EROL et al., 2008; TAVARES \& SERAFINI; 2003).

Levando-se em consideração a importância da pesquisa desse microrganismo em carnes, as especificidades de seu cultivo, a relevância da toxina cpe em surtos de toxinfecção alimentar, a ausência de pesquisas deste microrganismo em alimentos no Distrito Federal e Entorno e os escassos trabalhos no Brasil, esse trabalho teve por objetivos avaliar a presença de $C$. perfringens em carnes bovinas embaladas a vácuo, comercializadas na região do Distrito Federal e Entorno, fazendo a comparação entre o cultivo do microrganismo em jarra de anaerobiose, utilizando a passivação do cobre como método de geração de anaerobiose, e o cultivo em câmara de anaerobiose com mistura de gases contendo $85 \% \mathrm{~N}_{2}, 10 \% \mathrm{CO}_{2}$ e $5 \% \mathrm{H}_{2}$, bem como os meios de cultivo agar SPS e agar TSC. Avaliar a influência da incubação das amostras com caldo $\mathrm{BHI}$ e detectar a presença do gene da toxina cpe nas cepas isoladas por reação em cadeia da polimerase (PCR). 


\section{MATERIAL E MÉTODOS}

\subsection{Origem das amostras}

Foram adquiridas 54 amostras de carne bovina embalada a vácuo, de marcas diversas, provenientes das regiões administrativas do Distrito Federal e Entorno, entre os períodos de 01 de Maio e 15 de Dezembro de 2014. As amostras foram adquiridas simulando uma situação real de compra pelo consumidor, em que uma unidade amostral era caracterizada por uma peça de carne embalada a vácuo, sem sinal de violação, dentro do prazo de validade e inspecionada pelo Serviço de Inspeção Federal (SIF) ou pelo Departamento de Inspeção de Produtos de Origem Vegetal e Animal do Distrito Federal (DIPOVADF). As amostras foram transportadas ao Laboratório de Microbiologia de Alimentos da UnB (LAMAL-UnB) em caixas isotérmicas, sendo acondicionadas sob refrigeração até o momento do processamento.

As metodologias para isolamento de $C$. perfringens utilizadas foram os protocolos descritos por SILVA (2010), XIAO et al. (2012) e pela Instrução normativa numero 62 do Ministério da Agricultura, Pecuária e Abastecimento, de 2003 (BRASIL, 2003). Foram retirados fragmentos de $25 \mathrm{~g}$, de cada unidade amostral, bem como colhidos e armazenados $1,0 \mathrm{~mL}$ de exsudato de carne presentes no interior da embalagem. 


\subsection{Isolamento de Clostridium perfringens a partir de $25 \mathrm{~g}$ de amostra de carne bovina}

Antes da abertura das embalagens, as amostras foram higienizadas com álcool etílico $70 \%$, sendo em seguida coletados $1,0 \mathrm{~mL}$ de exsudato da carne para realização do enriquecimento em caldo $\mathrm{BHI}$. Todas as alíquotas foram armazenadas em freezer da marca Continental $\AA^{\circledR}$ sob a temperatura de $-10^{\circ} \mathrm{C}$.

Em seguida, pesou-se 25 gramas de cada amostra em sacos esterilizados para homogeneização de amostras BagLight $\circledast$, sendo em seguida adicionados $225 \mathrm{~mL}$ de água peptonada tamponada 1\%, formando então a diluição 1:10. A partir dessa diluição foram preparadas duas placas de Petri utilizando o método de "pour plate", com uma placa contendo Agar TSC® (Triptose, extrato de carne,digestão papáica de farinha de soja, extrato de levedura, metabisulfito de sódio, citrato férrico de amônio, D-cicloserina, Agar) e outra contendo Agar SPS® (Caseína enzimática hidrolisada, sulfito de sódio, citrato férrico, extrato de levedura, sulfadiazinha, sulfato de polimixina B, Agar). Também foram preparadas mais duas placas usando "spread plate", com os mesmos meios de cultivos TSC e SPS.

As placas foram incubadas de dois modos distintos. As placas preparadas em "pourplate" foram acomodadas em jarra de anaerobiose da marca Permution $\circledast$ $36{ }^{\circ} \mathrm{C}$, por 24 a 48 horas, tendo como método de geração de anaerobiose a passivação do cobre, de acordo com o recomendado por SILVA et al. (2010) e pela IN62/2003. As demais placas em "spread plate" foram acomodadas em câmara de anaerobiose do tipo Forma Anaerobic Systems $\AA$ da ThermoScientific $\circledast$ 
com mistura especial de gases contendo $85 \% \mathrm{~N}_{2}, 10 \% \mathrm{CO}_{2}, 5 \% \mathrm{H}_{2}$, sob a mesma temperatura e tempo.

\subsection{Isolamento de Clostridium perfringens a partir de exsudato de carne pré-enriquecido em caldo $\mathrm{BHI}$}

Foi inoculado $1 \mathrm{~mL}$ do volume coletado no processamento inicial em $9 \mathrm{~mL}$ de caldo BHI, para cada amostra de carne bovina analisada. Sendo incubado em câmara de anaerobiose a $36^{\circ} \mathrm{C}$ por 24 a 48 horas, segundo XIAO et al. (2012).

Após o período de pré-enriquecimento, o caldo inoculado foi utilizado para preparar 2 placas "pour plate", e 2 "spread plate" como descrito no processamento anterior. As placas em "pour plate" continham ágar SPS $\AA$ e TSC $\AA$ inoculou-se em cada uma delas a alíquota de $1 \mathrm{~mL}$ de caldo $\mathrm{BHI}$, emseguida foram incubadas em jarra de anaerobiose a $36^{\circ} \mathrm{C}$, por 24 a 48 horas, tendo como método de geração de anaerobiose a passivação do cobre. As placas em "spread plate" continham os mesmos meios de cultivo, e nelas inoculou-se uma alçada, contendo aproximadamente $5 \mu \mathrm{L}$ do caldo BHI e incubadas em câmara de anaerobiose sob a mesma temperatura e quantidade de tempo.

Foi considerado crescimento positivo o aparecimento de colônias negras e redondas características de Clostridium perfringens, como descrito no manual do ágar TSC $\circledast$ e ágar SPS®. Essas colônias foram submetidas à coloração de Gram para a observação dos bastonetes gram-positivos característicos da bactéria. 


\subsection{Análises estatísticas}

Para a verificação da ocorrência de Clostridium perfringens em amostras de carne bovinas comercializadas no Distrito Federal, a análise estatística empregada foi a de um estudo observacional, conforme descrito por PEREIRA (1995). Para a análise da influência do pré-enriquecimento com o caldo $\mathrm{BHI}$ e a incubação em câmara de anaerobiose, utilizou-se o teste do qui-quadrado de McNemar (PETRIE \& WATSON, 2006), tendo em vista o pareamento das amostras.

\subsection{Detecção do gene da toxina cpe por reação em cadeia da polimerase(PCR)}

Para a realização do PCR para a detecção do gene da toxina cpe, seguiuse o protocolo proposto por KANEKO et al. (2011). Todas as cepas que apresentaram crescimento característico de colônias negras e redondas, características de Clostridium perfringens foram submetidas à PCR. Para a reação foram utilizados os primers cpe-F3 (5' $A C A$ TCTGCAGATAGCTTAGGAAT3') e cpe-B3 (5' CCAGTAGCTGTAATTG TTAAGTGT 3'), descritos por MIKI et al. (2008). As reações ocorreram com um volume final de $25 \mu \mathrm{l}$, contendo $2,0 \mathrm{mM} \mathrm{MgCl}, 2 \mu \mathrm{l}$ de $2 \mathrm{mM}$ dNTPs, $1 \mu \mathrm{l}$ de $10 \mathrm{pmol}$ de cada primer, 2,5U Taq DNA polymerase (Phoneutria), 2,5 $\mu$ de tampão PCR 10X e como template utilizaram-se as próprias colônias características de $C$. perfringens. A amplificação foi realizada em termociclador da marca MyCycler ${ }^{\mathrm{TM}}$ ThermalCycler®, com um ciclo inicial de $94^{\circ} \mathrm{C}$ por 2 minutos, seguido por 35 ciclos a $94^{\circ} \mathrm{C}$ por 30 segundos, $55^{\circ} \mathrm{C}$ por 30 segundos e $68^{\circ} \mathrm{C}$ por 30 segundos, e uma extensão final de $68^{\circ} \mathrm{C}$ por 8 minutos. Após a amplificação, os produtos da PCR 
foram analisados em gel de agarose 1,5\%, com concentração de $5 \mu \mathrm{g} / \mathrm{ml}$ de brometo de etídio, esperando-se encontrar produtos com 248 pares de bases.

\section{Resultados e discussão}

\subsection{Isolamento de Clostridium perfringens a partir de 25 gramas de amostra de carne bovina}

Das 54 amostras analisadas em Agar TSC e Agar SPS, e incubadas tanto em jarra de anaerobiose quanto em câmara de anaerobiose, em apenas uma (01) amostra observou-se crescimento em ambos os meios de cultivo e em ambos os método de incubação. Nas demais amostras não foi observado nenhum crescimento. Obtendo-se desta forma a ocorrência de 1,85\%.

TAVARES \& SERAFINI (2003) encontraram C. perfringens em apenas $2 \%$ do total de 100 amostras de hambúrgueres de carne bovina, comercializados no município de Goiânia. Estes autores utilizaram o método de incubação em jarra de anaerobiose, sendo similares aos resultados observados neste estudo, em semelhantes condições. FILHO et al. (2006) avaliaram a presença de $C$. perfringens em meias-carcaças bovinas provenientes de abatedouros do Estado de Goiás. Em seu estudo não foi observado crescimento de C. perfringens em nenhuma das amostras analisadas, divergindo dos resultados obtidos neste estudo. Apesar de não se tratar de matriz da mesma espécie, os resultados deste trabalho também se diferenciaram dos obtidos por KOUASSI et al. (2014), que pesquisaram C. perfringens em 395 cortes de carne de aves na Costa do Marfim e evidenciaram a presença de C. perfringens em 5,06\% das amostras. HUANG (2015) avaliou os efeitos do cozimento na ativação de esporos, e isolou 
Clostridium perfringens a partir de amostras de carne previamente inoculadas com o microrganismo, utilizando ágar TSC como meio cultivo e fazendo incubação em câmara de anaerobiose, de tal maneira que observou crescimento de $C$. perfringens em todas as amostras preparadas, sendo desta forma similar à este trabalho, no que se refere à utilização do meio de cultivo e forma de incubação.

\subsection{Isolamento de Clostridium perfringens a partir de exsudato de carne pré - enriquecido com caldo BHI}

Foi observado crescimento em todas as amostras preparadas em placas de Petri contendo Agar SPS $\AA$ e Agar TSC $\AA$, incubadas tanto em jarra de anaerobiose quanto em câmara de anaerobiose $\left(85 \% \mathrm{~N}_{2}, 10 \% \mathrm{CO}_{2}, 5 \% \mathrm{H}_{2}\right)$, perfazendo um total de $100 \%$. Como demonstrado na Tabela 1.

Tabela 1. Pesquisa de C. perfringens em 54 amostras de exsudato de carne bovina, com etapa de pré-enriquecimento prévio em caldo $\mathrm{BHI}$, com incubação em jarra de anaerobiose e câmara de anaerobiose, em meios de cultivos ágar SPS e ágar TSC.

\begin{tabular}{lll}
\hline Pesquisa de & Agar SPS & Agar TSC
\end{tabular}

Clostridium perfringens

\begin{tabular}{lll}
\hline Incubação em jarra de & $54 / 54(100 \%)$ & $54 / 54(100 \%)$ \\
anaerobiose & & $54 / 54(100 \%)$ \\
Incubação em câmara de & $54 / 54(100 \%)$ & \\
anaerobiose & &
\end{tabular}


Diversos autores obtiveram resultados positivos ao utilizar o caldo $\mathrm{BHI}$ como meio de pré-enriquecimento para recuperação de esporos de $C$. perfringens (XIAO et al., 2012, KANECO et al., 2011, WEN \& MACCLANE, 2004). XIAO et al. (2012) utilizaram o BHI para induzir a germinação de esporos de cepas $C$. perfringens isoladas de 98 alimentos diversos provenientes da inspeção sanitária da Holanda. Neste estudo os autores observaram a recuperação de esporos em todas as amostras, semelhante aos resultados obtidos neste trabalho, com a matriz carne bovina. KANEKO et al. (2011) em sua pesquisa sobre deteç̧ão de $C$. perfringens enterotoxigênico em amostras de carne bovina no Japão, utilizaram o enriquecimento prévio em $\mathrm{BHI}$ para realizar contagem de células bacterianas viáveis, e como nesse estudo, observaram a eficiência da recuperação de esporos de $C$. perfringens em suas amostras. O mesmo foi observado por WEN \& MACCLANE (2004), que utilizaram o ágar BHI incubado em jarra de anaerobiose para recuperação de esporos de $C$. perfringens, em alimentos não envolvidos em surtos de toxinfecção alimentar, observando crescimento característico de $C$. perfringens em 290 do total de 900 amostras.

Estes resultados corroboram com os obtidos neste estudo, em que a eficiência de se promover a etapa do pré-enriquecimento em caldo $\mathrm{BHI}$ é demonstrada. Em todos os trabalhos, os autores se mostram unânimes quanto à eficiência do caldo BHI na germinação de esporos de C. perfringens. Destaca-se a importância da câmara de anaerobiose, que possibilitou a realização da etapa de pré-enriquecimento em condições ideais de anaerobiose e segurança, sem as quais não seria possível sua realização. Entretanto, há que se ressaltar o alto custo para a implantação e manutenção deste equipamento, bem como os seus insumos, como demonstrado por JOUSIMIES-SOMER et al. (2002). 
Não há, no Brasil, metodologia oficial que estabeleça o uso do caldo BHI para recuperação de esporos de $C$. perfringens tanto em câmara de anaerobiose quanto em jarra de anaerobiose. $O$ cultivo de esporos de $C$. perfringens em meio líquido apresentou, neste trabalho, resultado satisfatório, e uma possível justificativa é a maior disponibilidade de nutrientes em meio líquido, que favorece a recuperação de cepas, que antes estariam inviáveis para o cultivo em meio sólido (SULA \& SUNDARESAN, 1963). Vale ressaltar que não foi realizada a etapa de pré-enriquecimento em tubos contendo caldo $\mathrm{BHI}$ em jarra de anaerobiose por inviabilidade operacional, portanto são necessários mais estudos com o intuito de avaliar a viabilidade do processo de incubação do caldo $\mathrm{BHI}$ em jarra de anaerobiose, considerando que este é um método clássico e eficiente de se gerar atmosfera anaeróbia (JOUSIMIES-SOMER et al., 2002).

$\mathrm{Na}$ análise estatística através do teste do qui-quadrado de McNemar, observou-se diferença significativa $(p<0,001)$ entre 0 cultivo sem préenriquecimento e com pré-enriquecimento, comprovando que o meio $\mathrm{BHI}$ teve efeitos positivos na recuperação de esporos de $C$. perfringens, (Tabela 2). 
Tabela 2. Teste do Qui-quadrado para a comparação da pesquisa de $C$. perfringens em 54 amostras de carne bovina comercializada no Distrito Federal, com e sem etapa de pré-enriquecimento em caldo BHI.

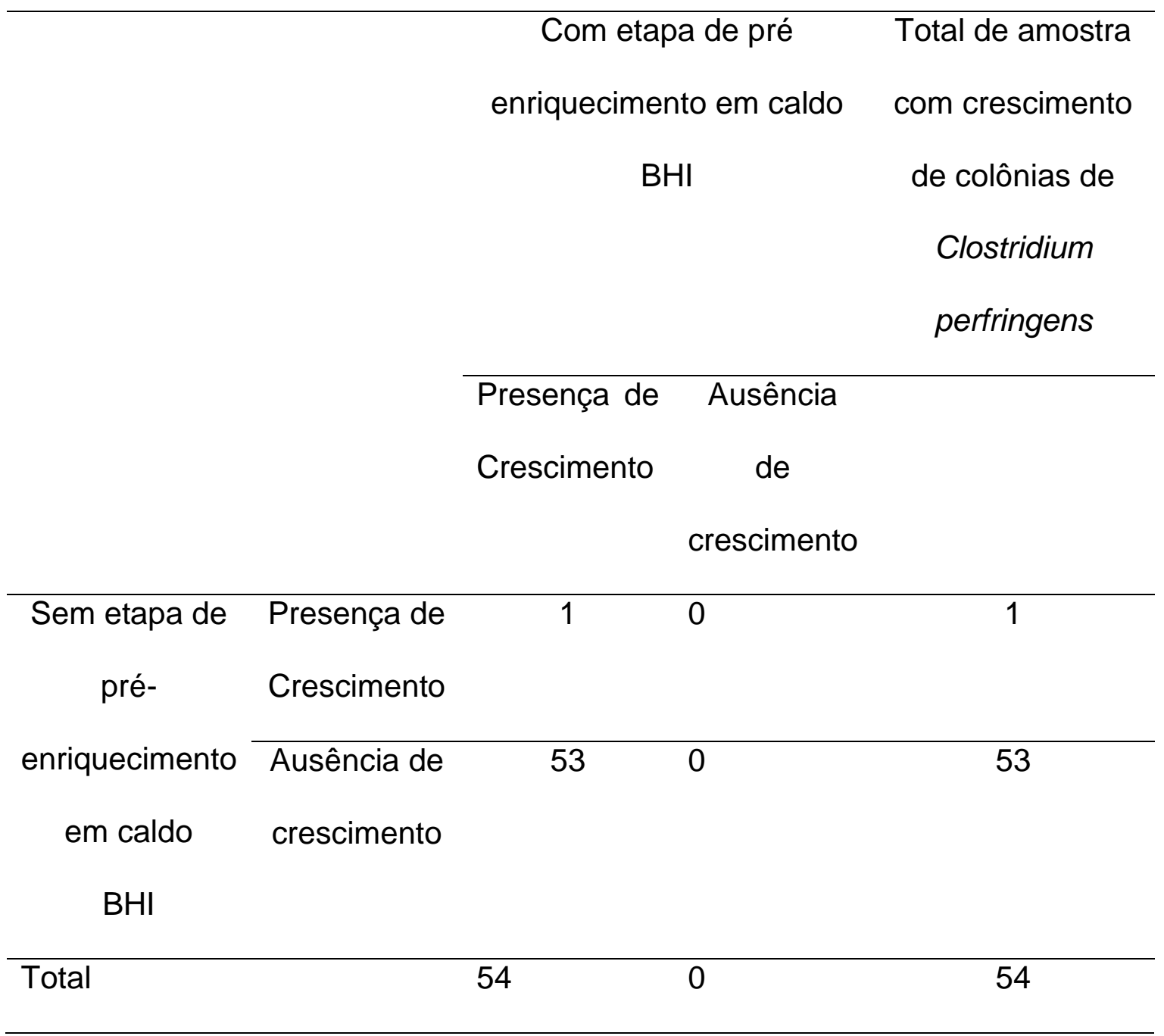

Não foi encontrado nenhum estudo comparando o crescimento entre cepas de C. perfringens, com e sem etapa de pré-enriquecimento em caldo $\mathrm{BHI}$, inoculação em ágar SPS e ágar TSC com fase de incubação em jarra de anaerobiose e câmara de anaerobiose. No entanto, no trabalho SUMMANEN et al. (1999) foi comparado o crescimento de 54 cepas bactérias anaeróbias em Agar Brucella e a recuperação de bactérias anaeróbias a partir de 31 espécimes 
clínicos em ágar Brucella reduzido e ágar BEE, utilizando três métodos distintos de geração de anaerobiose: uma Anoxomat $\AA$, um sistema de GasPak® e uma câmara de anaerobiose. Apesar de não ter sido observada diferença significativa no crescimento e recuperação de bactérias anaeróbias entre os três métodos de geração de anaerobiose, os resultados do estudo sugerem que o sistema Anoxomat $\AA$ foi o mais eficiente entre três métodos comparados, por sua capacidade de gerar uma atmosfera anaeróbia satisfatória e ocupar pouco espaço físico. Similarmente, neste estudo não foi observada diferença significativa $(P<0,001)$ entre o uso da jarra de anaerobiose com passivação de cobre e da câmara de anaerobiose no crescimento de C. perfringens.

\subsection{Detecção do gene da toxina cpe por reação em cadeia da polimerase (PCR)}

Todas as cepas provenientes do cultivo das 54 amostras de carne bovina cultivadas em agar SPS $\circledast$ e TSC $\circledast$, incubadas tanto em jarra de anaerobiose, quanto em câmara de anaerobiose, que demonstraram crescimento característico de C. perfringens, obtidas com e sem o pré-enriquecimento em caldo $\mathrm{BHI}$, foram submetidas a detecção da toxina cpe por PCR, perfazendo portanto um total de 110 reações. Desse total, nenhuma apresentou amplificação para a presença da toxina, que indicaria a produção de enterotoxina responsável por intoxicação alimentar. Semelhante à este trabalho, FERREIRA et al. (2012) ao realizarem tipagem molecular de cepas de C. perfringens, oriundas de abatedouros de suínos do Estado de São Paulo também não encontraram nenhuma amostra positiva para o gene cpe. GOMES et al. (2008) não encontraram amostras positivas para a toxina cpe em 171cepas oriundas de amostras de carne de 
frangos de corte, provenientes do Estado de Minas Gerais. Entretanto, LAHTI et al. (2008) ao trabalhar com C. perfringens isolados a partir de alimentos comprovadamente envolvidos em surtos de toxinfecção alimentar, observou que 91\% do seu total de 53 amostras apresentavam a toxina cpe, detectadas por PCR.

Apesar de nenhuma das cepas isoladas não possuírem o gene produtor da toxina cpe, não se pode afirmar que ele esteja ausente na região do Distrito Federal e Entorno, tendo em vista o número de amostras analisadas neste estudo. Maiores estudos devem ser conduzidos para se verificar a real presença deste microrganismo, bem como a deteç̧ão da toxina cpe.

\section{CONCLUSÃO}

Foi verificada a presença de $C$. perfringens em amostras de carne bovina embaladas a vácuo, comercializadas na região do Distrito Federal e Entorno, no entanto nenhuma cepa isolada neste estudo apresentou a toxina cpe, pelo método de detecção por PCR. Também não foi observada diferença entre os meios de cultivos ágar SPS e ágar TSC. Destaca-se a recuperação de esporos de C. perfringens em caldo $\mathrm{BHI}$, o qual foi significativamente diferente, demonstrando a eficácia do meio de cultivo, com incubação em câmara de anaerobiose, evidenciando a presença de esporos viáveis nas carnes bovinas, embaladas à vácuo. São necessários mais estudos com um numero maior de amostras para se avaliar a real situação sanitária, no que se refere à presença desta bactéria, bem como avaliar a presença da toxina cpe,em carnes embaladas a vácuo comercializadas no Distrito Federal e Entorno.

\section{REFERENCIAS}


AKHTAR, S.; PAREDES-SABJA, D.;TORRES, J.A.;, SARKER, M.R.. Strategy to inactivate Clostridium perfringens spores in meat products. Food Microbiology.V. 26 n.3 pag. 272-277. 2009.

AL-QADIRI, H.; SABLANI, S. S.; OVISSIPOUR, M.; AL-ALAMI, N.; GOVINDAN, B.; RASCO, B. Effect of oxygen stress on growth and survival of Clostridium perfringens, Campylobacter jejuni, and Listeria monocytogenes under different storage conditions.Journal Of Food Protection. V. 78, n.4, pag.691-697. 2015

BRASIL; MINISTÉRIO DA AGRICULTURA PECUÁRIA E ABASTECIMENTO. Instrução normativa número 62. Brasília, Distrito Federal. 2003.

BRASIL; MINISTÉRIO DA SAÚDE; DEPARTAMENTO DE VIGILANCIA EPIDEMIOLÓGICA; COORDENAÇÃO GERAL DE DOENÇAS TRANSMISSÍVEIS. Vigilancia Epidemiológica Das Doenças Transmitidas por Alimentos - VE-DTA. São Paulo. 2014. Disponível em <http://www.anrbrasil.org.br/new/pdfs/2014/3_PAINEL_1_ApresentacaoRejaneAlv esVigilanciaEpidemiologica-VE-DTA-Agosto_2014_PDF.pdf>. Ultimo acesso em: 18 de Junho de 2015

CDC. CENTERS FOR DISEASE CONTROL AND PREVENTION. Clostridium perfringens. Foodbornesafety. 2014. Disponível em <http://www.cdc.gov/foodsafety/clostridium-perfingens.html >. Ultimo acesso em: 22 de Junho de 2015. 
CHEN, J.;, MA, M.;, UZAL, F.A.;, MCCLANE, B.A. Host cell-induced signaling causes Clostridium perfringens to upregulate production of toxins important for intestinal infections.Gut Microbes. V.5 n.1 pag. 96-107. 2014

DESMARAIS, T.R.; SOLO-GABRIELE, H.M.;, PALMER, C.J. Influence of soil on fecal indicator organisms in a tidally influenced subtropical environment. Applied and Enviromental Microbiology. V.68 n.3 pag.1165-1172. 2002.

EROL, I.; GONCUOGLU, M.; AYAZ, ND.; BILIR ORMANCI, FS.; HILDEBRANDT, G. Molecular typing of Clostridium perfringens isolated from turkey meat by multiplex PCR. Letters in Applied Microbiology.V.47, n.1, pag.31-34. 2008.

FERNANDEZ-MIYAKAWA, M.E, MARCELLINO, R, UZAL, F.A. Clostridium perfringens type A toxin production in 3 commonly used culture media.. Journal of Veterinary Diagnostic Investigation.V. 19, n.2, pág. 184-186. 2007.

FERREIRA, T. S. P.; MORENO, A. M.; ALMEIDA, R.R; GOMES, C. R.; GOBBI D. D. S.; FILSNER, P. H. N. L.; MORENO, M. Molecular typing of Clostridium perfringens isolated from swine in slaughterhouses from São Paulo State, Brazil. Ciencia Rural.V.42, n.8, pag.1450-1456. Ago. 2002.

FILHO, A.T.F; MESQUITA, A. J. M.; OLIVEIRA, J.P.; BUENO, C.P.; LOPES, J.H.; COUTO, M.V.; BORGES, N. M. F.; Qualidade bacteriológica de meias-carcaças bovinas oriundas de matadouros-frigoríficos do estado de Goiás habilitados para exportação. Ciência Animal Brasileira.v. 7, n. 3, p. 315-325. 2006. 
GOLDSTEIN, M.R.; KRUTH, S.A.; BERSENAS, A.M.; HOLOWAYCHUK, M.K.; WEESE, J.S.Detection and characterization of Clostridium perfringens in the feces of healthy and diarrheic dogs.Canadian Journal of Veterinary Research. V.76 n. 3 pag.161-165. 2012.

HUANG, L. Dynamic determination of kinetic parameters, computer simulation, and probabilistic analysis of growth of Clostridium perfringens in cooked beef during cooling. International Journal of Food Microbiology. n.195pag. 20-29. 2015

JOUSIMIES-SOMER, H.; WADSWORTH-KTL. Anaerobic Bacteriology Manual. 6a edição. Editora Starpub. 287 páginas. 2002.

KANEKO, I.; MIYAMOTO, K.; MIMURA, K.; YUMINE, N.; UTSUNOMIYA, H.; AKIMOTO, S.; MCCLANE, B.A.Detection of enterotoxigenic Clostridium perfringens in meat samples by using molecular methods. Applied and Enviromental Microbiology. V.77, n. 21, pag.7526-7532. 2011.

KOUASSI, K.A.; DADIE, A.T.; N'GUESSAN, K.F.; DJE, K.M.; LOUKOU, Y.G. Clostridium perfringens and Clostridium difficile in cooked beef sold in Côte d'Ivoire and their antimicrobial susceptibility. Anaerobe.28:90-94. 2014.

LAHTI P.; HEIKINHEIMO A.; JOHANSSON T.; KORKEALA H. Clostridium perfringens type A strains carrying a plasmid-borne enterotoxin gene (genotype 
IS1151-cpe or IS1470-like-cpe) as a common cause of food poisoning. Journal of Clinical Microbiology.V. 46, n. 1pag. 371-373. 2008.

LI, J., MCCLANE, B.A.The Sialidases of Clostridium perfringens type D strain CN3718 differ in their properties and sensitivities to inhibitors.Applied and Environmental Microbiology. V. 80, n. 5, pag. 1701-1709. 2013

LOBATO, F.C.; LIMA, C.G.; ASSIS, R.A.; PIRES, P.S.; SILVA, R.O.; SALVARANI, F.M; CARMO, A.O.; CONTIGLI, C.; KALAPOTHAKIS E. Potency against enterotoxemia of a recombinant Clostridium perfringens type $D$ epsilon toxoid in ruminants.Vaccine.V.28, N. 38, pag.6125-6127. 2010.

MIKI, Y.; MIYAMOTO, K.; KANEKO-HIRANO, I.; FUJIUCHI, K.; AKIMOTO, S. Prevalence and characterization of enterotoxin genecarrying Clostridium perfringens isolates from retail meat products in Japan. Applied Environmental Microbiology.V.74, n. 17, pag.5366-5372. Setembro. 2008.

PAREDES-SABJA D.; CARKER M.R.Host serum factor triggers germination of Clostridium perfringens spores lacking the cortex hydrolysis machinery. Journalof medical microbiology. V.60, n.12, pag.1734-1741. 2012.

PEREIRA, M. G. Epidemiologia: teoria e prática. Editora: Guanabara-koogan. 583p. 1995 
PETRIE, A.; WATSON, P. Estatistica em ciência animal e veterinária. $2^{a}$ edição.EditoraRocca. 2003.

PHAC.PUBLIC HEALTH AGENCY OF CANADA. Clostridium perfringens. Pathogens Safety Data Sheet.Disponível em: <http://www.phac-aspc.gc.ca/labbio/res/psds-ftss/clostridium-perfringens-eng.php>Ultimo acesso em: 21 de Junho de 2015.

PIRES, P.S.P.; SILVA, R.O.S.; LOBATO, F.C.F. Clostridiose alimentar Clostridium perfringens. Programa de zoonoses - região sul. 2011 Disponível em: <http://www.zoonoses.org.br/absoluto/midia/imagens/zoonoses/arquivos_1330097 103/3829_clostridiose_alimentar_c_perfringens.pdf>. Ultimo acesso em: 08 de junho de 2015.

SHINDO, Y.; DOBASHI, Y.; SAKAI, T.; MONMA, C.; MIYATANI, H.; YOSHIDA, Y. Epidemiological and pathobiological profiles of Clostridium perfringens infections: review of consecutive series of 33 cases over a 13-year period. International Journal of Clinical and Experimental Pathology.V. 8, n. 1, pag.569-577.2015

SILVA, N. Manual de métodos de análise microbiológica de alimentos e água. 4. Ed. São Paulo: Varela, 2010.

SULA, L.; SUNDARESAN, T.K.WHO co-operative studies on a simple culture technique for the isolation of mycobacteria. 2. Comparison of the efficacy of 
lyophilized liquid medium with that of loewenstein-jensen (I-j) medium. Bulletin of the World Health Organization. V.29, pag.607-625. 1963.

SUMMANEN, P.H.; MCTEAGUE, M.; VÄISÄNEN, M.L.; STRONG, C.A.; FINEGOLD, S.M.Comparison of recovery of anaerobic bacteria using the Anoxomat, anaerobic chamber, and GasPak jar systems.Anaerobe.V.5, n.1, pag 5-9. 1999

TAVARES, T.M.; SERAFINI, A.B. Avaliação microbiológica de hamburgeres de carne bovina comercializados em sanduicherias tipo trailers em Goiania-GO. Revista de Patologia Tropical. V. 32, n.1, p. 45-52, jan-jun. 2003.

WEN, Q.; MACCLANE, B.A. Detection of Enterotoxigenic Clostridium perfringens Type A Isolates in American Retail Foods. Applied and Enviromental Microbiology. V.70 n.5pag.2685-2691. 2004

XIAO, Y.; WAGENDORP, A.; MOEZELAAR, R.; ABEE, T.; WELLS-BENNIK, M. H. A Wide Variety of Clostridium perfringens Type A Food-Borne Isolates That Carry a Chromosomal cpeGene Belong to One Multilocus Sequence Typing Cluster. Applied and Enviromental Microbiology. V. 78 n.19pag .7060-7068. 2012 